\title{
The Scarecrow, Narnia, and Jesus of Nazareth
}

\author{
Raúl Montero Gilete ${ }^{1}$ \\ ${ }^{1}$ Faculty of Arts, University of the Basque Country, Vitoria-Gasteiz, Spain \\ Correspondence: Raúl Montero Gilete, Faculty of Arts, University of the Basque Country, Vitoria-Gasteiz, Spain. \\ E-mail: raul.monterog@ehu.es
}

\author{
Received: March 14, 2013 Accepted: May 13, 2013 Online Published: May 29, 2013 \\ doi:10.5539/res.v5n2p60 URL: http://dx.doi.org/10.5539/res.v5n2p60
}

\begin{abstract}
This article presents the Scarecrow Literature as a sub-genre of Fantasy literature, which was born in Anglo-Saxon countries in the 20th century. In it, a variety of traditions, cultures and religions are intertwined. They have several common characteristics: they embody and update Christianity's values, they employ fantastical clothing and use imagination as a tool. In this sub-genre, children make a journey from our world to a secondary world, as happens with the Pevensie children and other young characters in Narnia. And depending upon the historical moment in which the writer in question places their work, the setting is generally rural and is steeped in pagan tradition. It is here where the children perform some heroic mission. When the adventure concludes, the young heroes return to their primary world, while maintaining their anonymity, and as a reward for their work obtain the warmth of family or community.
\end{abstract}

Keywords: Narnia, hero, children's literature, scarecrow literature, Jesus of Nazareth

\section{Introduction}

Children feel a peculiar attraction to super heroes and idols be it in the world of cinema, music, literature, or sports. This simple observation gave rise to the thought that all of these figures possess a commonality and embody something rather special to have captured the imagination of children to the degree they have, as is evidenced in children's games and in their daily conversations. In our case, this curiosity became an obsession. We try to understand how the literature that deals with these figures could have exercised such an influence on its readers.

We began by examining works which in various encyclopedias, Internet pages and scholarly articles the Anglo-Saxon world includes in its literary canon — works like Alice's Adventures in Wonderland (1864), The Wonderful Wizard of $\mathrm{Oz}$ (1900), Peter and Wendy (1911), The Hobbit (1937), The Lion, the Witch and the Wardrobe (1950), and Harry Potter and the Philosopher's Stone (1997). We discovered that the young heroes featured in these works, by and large, did not coincide with the classic heroic typology wherein the hero, all-powerful and perfect, experiences an incredible adventure from which he —usually a man - always emerges victorious. This deviation prompted us to believe that perhaps we had encountered a new literary sub-genre in which a different heroic archetype emerged and, as such, begged further study. With this article, our contribution to the academic world is twofold: firstly, to identify and establish the framework for a new typology of the hero in children's literature described by the critical term Scarecrow Literature to articulate it; secondly, to present the young characters in The Chronicles of Narnia and the Biblical Jesus of Nazareth as heroes of the type of literature.

To date, the Spanish academic world has scarcely taken note of investigations that make reference to the child as hero in children's fantasy literature. When speaking about The Chronicles of Narnia, the theme of youthful heroism is rather beyond discussion (Kirk, 2005; Shea, 1993). Yet neither of these concerns themselves with children as heroes of the story, and as such does little to focus on the line of investigation we wish to pursue. In fact, given the existing gap in investigation into the concept of child as hero in general, and in The Chronicles of Narnia in particular, we find it opportune to set the present article within that unexplored framework. Moreover, we deal with the symbolism of the figure of the scarecrow and its relation to the world. We will try to demonstrate the elasticity of the heroic typology of Children's Scarecrow Literature that appears in Lewis's work and attempt to apply this new postulate to the figure of Jesus of Nazareth and observe the results to determine if Jesus might be considered a hero in this type of literature.

\section{The Scarecrow}

20th century literature has produced various writers who have tried to set forth a different vision of the world; a world in which all things possess intrinsic value. Works such as The Wonderful Wizard of Oz by Frank L. Baum, 
Peter Pan and Wendy by J. M. Barrie, The Chronicles of Narnia by C. S. Lewis, The Neverending Story (1979) by Michael Ende, The Talisman (1984) by Stephen King and Peter Straub, Harry Potter and the Philosopher's Stone by J. K. Rowling, or His Dark Materials (2000) by Philip Pullman express a desire to renew our vision of this world by means of a journey to another, often a "pseudo-medieval" place of markedly rural character and varying degrees of sophistication. They intend to help us shape the vision of our primary world through a journey to a richly conceived secondary world whose values have much to offer us.

The above-named works share common characteristics: some of their heroes are not yet adults (Dorothy, Wendy, Digory, Polly, Peter, Edmund, Susan, Lucy, Eustace, Jill, Bastian, Jack, Richard, Will, Harry, Lyra and Hill); they travel to a place threatened by an imbalance; they are transformed after having restored the balance and learn to love the world for what it is. In addition, all these works have found a large audience among children and adult readers. For some reason, they seem to touch a chord with many readers, perhaps by reminding them that they have not always been deprived of imagination, nor separated from the natural world. Despite the fact that each of the works mentioned above is different, we they have a common symbol. However, it is not the scar, or the lion, or the flying boy - but the scarecrow.

The concept of balance is central to the nature of the scarecrow, indeed its own morphology points towards equilibrium. In various cultures scarecrows are used to protect crops by frightening birds though not — and this is important - harming them. Implicit in this is a respect for the balance in nature, for the hostile as well as the benign. Yet respecting the dual forces of creation and destruction does not negate the scarecrow's clear preference for the former, in-so-far as it is tasked with preservation and protection of crops.

The human cultures that spawned the scarecrow displayed a similar attitude toward nature. They learned to utilize and harness its creative force while coming to respect, if not fear its destructive side. Recognizing the sacred character of the whole of creation, including the forces of violent lightning, thunder and wind, man created myths to explain the meaning of nature's hostile behaviour and art to capture its harmony; to beautify his immediate surroundings as well as cultivate food for the livelihood of his community (Hamilton, 1942). The symbol of Christianity is not incompatible with the morphology of the scarecrow. The cross of Christ mirrors the arrangement of sticks which form the basic structure of a scarecrow.

In The Hero With a Thousand Faces, Joseph Campbell introduced the idea of androgyny in reference to the nature of God. However, the scarecrow, as the embodiment of a profound mixture of traditions moves beyond this. On the one hand, while the scarecrow mimics human beings, it traditionally lacks legs or indeed is cut off at the waist and is, therefore, sexless. It is neither male nor female, but it can be both. To some extent, the scarecrow is an asexual entity or being of both sexes at the same time and, at the same time, not being any. 'For in the language of the divine pictures, the world of time is the great mother womb. The life therein, begotten by the father, is compounded of her darkness and his light' (Campbell, 1949:156). Further, the scarecrow does not represent a patriarchal culture, as does Christianity. It is closer to pagan paradigms, which give value and space both to women and men, and which see them as playing equally important parts in a much larger natural system. On the other hand, the scarecrow represents a human figure that is in no way separated from the natural world. It is a figure that represents a version of our species. It mimics the human figure, and is rooted in the land; a strange symbiosis between the natural world and the people.

A casual glance at the literary works listed above and their enduring popularity attests to a deep yearning to recover the lost connection with the natural world and the cyclical nature of time. Disequilibrium is uncomfortable. The balance between man and nature, past and future shifts when a human being is placed at the centre of this universe. Time becomes a seemingly endless lineal progression moving toward no specific end. Society marches on, or indeed rushes headlong towards some undefined future. And this displacement of nature at the core of existence creates imbalance. So amidst the onward rush toward the unknown, it is understandable that we might feel cast adrift or lost. Those who find themselves attracted to the ideology that the scarecrow represents, do not seek an end to real progress, but simply to change a mindset that aligns itself with progress at any price; a mentality so focused on the present that it does not see - or prefers not to see - that a step forward today may inevitably force us two steps back the next. Modern society has distilled every issue, whether local or global, to a question of sheer profitability. The consecration of economic growth has created a maelstrom of consumption and exploitation in which the value of a tree is measured only in terms of the income it can generate within any given market sector. 'Nature,' said C. S. Lewis, 'has the air of a good thing that has been spoiled. It is not only spoiled in and of itself, but also in our human relationship to it.' (Duriez, 2002:147).

Where do we perceive the presence of the scarecrow in the works that we mentioned at the beginning of this section? First of all, it exists in the expression of the idea to renew our vision of the world through a "secondary 
world". This alternate universe is imbued with many of the cultural and religious elements of the world in which we live. In the case of The Lion, the Witch and the Wardrobe, the first of the works written by C. S. Lewis for The Chronicles of Narnia, we have a story about children traveling to a rural, pseudo-medieval world populated both by mythological beings such as fauns and Centaurs, and by Christian figures as well. Note the case of Aslan, the lion who sacrifices himself to save the others, and experiences a glorious resurrection. The children, aided by some animals and threatened by others, embark on a search for a means to restore the natural and moral balance in a world where winter never ends and where the White Witch turns elements of the natural world into decorative objects. Edmund, the child who succumbs to the temptation is, in principle, seduced by the material enticements of the witch. Eventually when he realizes that only suffering and pain hide behind her words, he learns the universal values of generosity and forgiveness - Christian values - through the example of Aslan. The witch is defeated, and with her disappearance, the cyclical change of seasons resumes — natural pagan values-, thereby restoring the natural and temporal balance.

The Chronicles of Narnia offers a fusion of the pagan with the Christian (Downing, 2005). Lewis propounded that there were many people who, regardless of their religion or beliefs, and who without knowing it, were Christian. 'Lewis can't be judged hardly for believing in his religion and disbelieving others. Of course he didn't rate Islam or Hinduism or Judaism as highly as Christianity. He thought they were essentially wrong. However, judged even by the standards he set for himself, Lewis's attitude towards other religions is surprisingly bigoted' (Colbert, 2005:178-86). For him, Christianity was like a sea into which all other religions flowed like rivers. But if we suppose that Lewis was wrong, that Christianity does not stand above any other belief or religion or god. Let us consider all religions as essentially the same. What then?

Then we must find an element that resonates for all readers, a general motif that flows through the story and blends God, nature and man. We believe that when Lewis tried to do this his success was relative. With the figure of the lion Aslan as God, he creates an icon that is valid. For many, the lion is a most noble, majestic and powerful animal; he is the King of the jungle, as Christ is also Heavenly King. The lion need not be man's enemy, its habitats are different. However, we cannot ignore the fact that the lion is carnivorous. If we were to face one inside its cage, no matter how very benign Lewis might have presented it, the lion would not hesitate to devour us. This fact does not prevent our seeing a Christ-God in Aslan, as numerous studies suggest (Bruner \& Ware, 2005; Downing, 2005).

Now consider a universal image rooted in the rural, a figure grounded in the traditions of our world, both Christian and Pagan, a figure with a mysterious past, who is environmentally friendly and who respects the well being of man and animals. That image is a scarecrow. The scarecrow is common to all five continents and in all of them it performs the same function: to protect the crop from animals so as to feed man; to frighten away birds and by so doing protect them from man's attacks. All of this is done while imitation the human figure that is rooted in the Earth. For this reason, could we consider the image of the scarecrow as a successful harmonizer of many positive qualities attributed to different deities? In his research, Haining (1988) suggests that the scarecrow is one of the most familiar figures of the rural landscape in Europe, 'Yet, despite all his fame, the origins and the development of the scarecrow have remained obscured in mystery... no one really knows the true origin of the Scarecrow.'

Now we could well speak of the scarecrow as a movement, or as the voice of a common feeling expressed through literature or other forms of art or action. However, in this article, to avoid being diverted from our initial objective, we will discuss only the part in which we propose to classify the Scarecrow Literature as a subgenre of Children's Fantasy literature.

\section{Scarecrow Literature}

The twentieth century has been the historical moment in which Children's Literature has shone with its own light. In the year 1900, the American writer Lyman Frank Baum wrote The Wizard of $O z$, a marvelous book whose story revolves around a girl, Dorothy, who is carried by a cyclone from Kansas to the world of magical characters and incredible adventures of Oz. Four years later, J. M. Barrie published Peter Pan and Wendy. In this fantasy adventure, Wendy, travels with her brothers and sisters in the surprising company of a character called Peter Pan, to the country of Never Land. The reader may well wonder what connects these two books and why the need exists for a sub-classification like Scarecrow Literature. We must admit that it is difficult to find an appropriate definition. It is as if we were presented with the situation of cataloguing an animal that seemed to be of the same breed as another and then which, after having been observed carefully, proved to be of a species different to any which had existed up to that point.

We can say that both novels were written by Anglo-Saxon writers in the English language in the early 20th century and that their prime target is a children's audience. In the two books, ordinary children from our world (Dorothy and Wendy) are transported to other secondary worlds where they experience incredible adventures. In these 
books, the majority of the subgenres of fantasy literature make an appearance: fantasy animal (animals that speak), toy fantasy (men of tinplate with human characteristics), eccentric character (the character of Peter Pan), supernatural and time fantasy (the adult vision of Peter Pan), science fiction and fantasy space (being transported by a cyclone), magical journeys and enchanted lands (Oz and Never Land), and heroic or quest fantasy (the characters of Dorothy, the Lion, the Tin man, the Scarecrow, Peter Pan, and Wendy). Similarly we find the characteristics that articulate the imagination: "agglutination", "hyperbolization" and "exaggeration". All of them converge and create agile, fun, ethical, moral and fantastic stories. At the end of the books, once having completed their corresponding risky adventures, the young heroes of the story return to our world happy and satisfied with the work they accomplished "on the other side". This type of literature is intended to reach the hearts of children and encourage them to believe in values such as love and friendship that will help them to become better people and succeed in doing so. In the mid-20th century, The Lion, The Witch and the Wardrobe, the first book of The Chronicles of Narnia by C. S. Lewis emerged from English literature and continued the line that The Wizard of Oz and Peter Pan had traced. In Lewis's work, children from London travel through a wardrobe to the incredible world of Narnia. It is here that they become the protagonists of spectacular events that will, without a doubt, turn children into heroes.

It should be pointed out at this time that two of the major subgenres of Children's Fantasy Literature found in these books comprise the basic structure of Scarecrow Literature: "enchanted journeys and magical lands", and "heroic or quest/high fantasy". The first explores the plot possibilities that provide the reason for the trip. The main characteristic of the second genre is the feat of the hero or heroine and his/her fight against the dark side in a world where good always defeats evil. Scarecrow Literature combines both, and expands the idea, offering us new opportunities. This new hybrid has evolved over time to become "a sub-genre of Fantasy literature. It was born in Anglo-Saxon countries along with the 20th century. In it, a variety of traditions, cultures and religions are intertwined. They have several common characteristics: they embody and update Christianity's values, they employ fantastical clothing and use imagination as a tool. In this sub-genre, children make a journey from our world to a secondary world, as happens with the Pevensie children and other young characters in Narnia. And depending upon the historical moment in which the writer in question places their work, the setting is generally rural and is steeped in pagan tradition. It is here where the children perform some heroic mission. When the adventure concludes, the young heroes return to their primary world, while maintaining their anonymity, and as a reward for their work obtain the warmth of family or community.

\section{Application of the Heroic Schema Proposed by Scarecrow Literature to the Figure of Jesus of Nazareth}

Otto Rank, in The Myth of the Birth of the Hero (1914), examines several myths of birth, including that of Jesus of Nazareth. Rank always observes the same pattern: there is a Queen and a King, God or Goddess or some other divine couple that bring a hero into the world, often with difficulty. Thanks to a dream, the arrival of the hero is anticipated (New Jerusalem Bible, Matt. 1:20-21) 'He had made up his mind to do this when suddenly the angel of the Lord appeared to him in a dream (...) "She will give birth to a son and you must name him Jesus, because he is the one who is to save his people from their sins", and this dream is sometimes accompanied by a warning to the father (Matt, 2:13) 'After they had left, suddenly the angel of the Lord appeared to Joseph in a dream and said, "Get up, take the child and his mother with you, and escape into Egypt, and stay there until I tell you, because Herod intends to search for the child and do away with him".

Up to this point, we believe that we can apply Rank's schema to the figure of Christ, but from there onwards, we disagree. Jesus, unlike other heroes, will not be abandoned to his fate in a box, basket or boat, floating on the water before being rescued and suckled by animals or people of humble condition. Further Rank states that when the hero grows and sees his/her real parents, he/she takes revenge against the father and finally receives his honors. But again, this characterization cannot be applied to the figure of Christ who, rather than being guided by revenge, promulgates forgiveness, that is, the opposite attitude. The figure of Jesus of Nazareth does not fit neatly into parameters that Rank establishes for coming to terms with myths. Christ's biographical and doctrinal profile do not sit well on the proposed outline and in several respects they do not coincide. So much in the same way that Rank has attempted to create a diagram to find common patterns within the stories of certain heroes, this article hopes to outline the common elements between Jesus and the hero in Scarecrow Literature. This article, is intended to be brief, and to serve as a premise for future research and discussion aimed to demonstrate that Jesus could well have been a hero of the Scarecrow Literature.

We are going to present an outline to justify the hypothesis of isolating a new literary subgenre that will find as its heroes both Jesus of Nazareth and a group of characters from The Chronicles of Narnia. This study contains an analysis which some readers may find disturbing, but we wish to clarify that we are not attempting to assess the 
divinity of Jesus, but rather try to demonstrate how the mythical figure of Jesus portrayed in the gospels could well be aligned with the critertia used to analyze the heroes of Scarecrow Literature.

In The Chronicles of Narnia, Aslan is presented as the creator of the world depicted in the novel, he imparts knowledge to the rest of the animals and it is by the grace of his singing that the rivers begin to flow, flowers to grow, and the young sun illuminates the land of Narnia. But first and foremost, Aslan is a God of love (Duriez, 2002), he looks with compassion on all creatures that suffer pain,whether they belong to Narnia or not. It is as if the Great Lion is not only the creator of that distant and mysterious land, but of all distant and mysterious lands that comprise the universe, including our own. Because of Digory, evil is introduced into the world of Narnia on the first day of its existence 'Our world, like Narnia, was made completely good. It was created sweet, refreshing, and clean. But something happened that spoiled the milk, invaded the apple' (Bruner \& Ware, 2005:10).

In the beginnings of the biblical story, evil also appears very early in Genesis when at the end of the episode of Lamech, it seems to indicate the initialization of a malignant trend that begins with the death of Abel at the hands of Cain. Digory is heir to a fate that seems to be present in both worlds and that is why Aslan calls him Son of Adam. Here, again, we see the hero as a mere instrument of the misfortune of a destiny which apparently cannot be avoided. In the same way that the serpent tempted Adam through Eve, Digory is prompted by the White Witch. Fortunately, Digory is capable of avoiding the temptation, rejecting it categorically. Lewis shows us God in the figure of a lion. But following the same line of thought, he could as easily stand for the scarecrow.

We have to remember that in The Magician's Nephew, Digory and Polly are transported to Charn, a world that is dying. Once there, Queen Jadis (the White Witch) is rescued from a certain death. The queen is nothing other than the essence of evil that the children later unintentionally bring to Narnia. She represents the darkness while Aslan, creator of Narnia, symbolizes the light of the young world which has just been born. Thus we are led to the thought that if She and He are darkness and light; and is it not necessary for one to exist before the other makes sense? Lewis chooses Digory as the hero for his initial adventure and as the one chosen to enter the garden where the magical tree grows and from which he must retrieve the magic apple. Can we think that a man-hero would have been able to pass the same test? What makes the difference is Digory's age. His young male sexual instincts are not manifested to the extent they would be in a teen or a grown man. Andrew Rilstone (2006) notes the importance that Lewis is going to give to the fact that his characters are children, and how with the loss of innocence and the onset of puberty, the magic, almost angelic, seasoning of childhood, disappears. This will be shown to have consequences, as in the case of Susan. And as demonstrated in the last book of the Chronicles, The Last Battle, it has devastating consequences. Perhaps for this reason, the boy can cope with the witch's temptation. Digory is not a virgin restraining the impetuosity of his tendencies, but rather a boy in whom they have not yet been manifested. what happens is that they have not demonstrated yet. This asexual element is, to some extent, similar to that in the Scarecrow, who is genderless.

Now suppose that as Jesus of Nazareth states, there is another world apart from ours (John, 18:36) 'Jesus replied "Mine is not a kingdom of this world; if my kingdom were of this world, my men would have fought to prevent my being surrendered to the Jews. As it is, my kingdom does not belong here". This world is governed by Yahweh who in turn is the father of Jesus. Yahweh, worried about the ills of the Earth and humans who are His children. As he cared about us, He decided to send his most-beloved son, Jesus to save us and restore us to a track, which as a species, we had deviated from. Thus obeying Yahweh's divine plan, Jesus was born among us. Therefore He traveled from his primary world (whatever the world of Yahweh and Christ may be called) to a secondary world (in this case, the Earth). If we look at this journey, we find stories in the Scarecrow Literature where practically the same pattern is repeated. The only exception is that in the latter case, the Earth will be the primary world from where a few children depart to help a secondary world (Narnia, Oz, Never Land...) which is threatened by some evil or is in danger of being destroyed.

Jesus as the son of Yahweh comes to us after having left his Kingdom, his primary world. When he arrives in this world, it is a world both pagan and rural. The world from which he comes can only be glimpsed through his words. We cannot know if Jesus is a child in his world or an adult, or even if these concepts have meaning. What we can demonstrate is that He feels like a child when $\mathrm{He}$ is in the world-kingdom of his father (his primary world) (Luke, 18:16-17) 'But Jesus called the children to him and said, "Let the little children come to me, and do not stop them; for it is to such as these that the kingdom of God belongs. In truth I tell you, anyone who does not welcome the kingdom of God like a little child will never enter it"; in reference to the Scarecrow Literature: children of the primary world travel to a secondary world. Thus far, the Nazarene seems to meet all the initial criteria to be considered a hero of the Scarecrow Literature. 
When children come into the secondary world, they become protagonists of incredible adventures full of magic, which help them in their personal learning, and lead them to a better understanding of the essence of their heroic condition. Children, through their adventure, become the heroes and saviors of the secondary world. They manage to re-establish the internal balance that was lost, and some, as in the case of Peter, Edmund, Susan and Lucy in The Lion, the Witch and the Wardrobe, may even grow up and become Kings.

In the Gospels we find that from the time Jesus is born in the secondary world (the Earth), He is the protagonist of incredible adventures. Three Wise Men come from the East guided by a star that leads them to the portal where he is born. Shortly afterwards, he must flee to Egypt because the evil King Herod wants to kill him. But the child Jesus grows as do his wisdom and skills. He is even capable of "making magic" (Mark 1:33-34) 'The whole town came crowding round the door, and he cured many who were sick with diseases of one kind or another; he also drove out many devils, but he world now allow them to speak, because they know who he was', and at the end of the story, Jesus becomes the hero of the secondary world returning the balance and the light for many people who walked in the dark (Matt, 28:18-20) 'Jesus came up and spoke to them. He said, "All authority in heaven and on earth has been given to me. Go, therefore, make disciples of all nations; baptize them in the name of the Father and of the Son and of the Holy Spirit, and teach them to observe all the commands I gave you. And look, I am with you always; yes, to the end of time". And in this secondary world, Jesus is even crowned as King by Roman soldiers (Luke, 23:38) 'Above him there was the inscription: This is the King of the Jews'. It is the secondary world, in the case of Jesus: the Earh, where the heroic work is performed.

Aslan's world, Narnia, is unbalanced because of the evil forces, whose embodiment is the White Witch who oppresses and terrorizes the Narnians. Children appear to restore the balance, emerging from the forest and, by their mere presence they return hope to the locals and allow Christmas to begin again. The case of the Earth is also similar. When Jesus appears in our world, in Judea, the land of the people chosen by God, Herod mimics the actions of the White Witch who rules Narnia, because he, like her, is also a tyrant in command of a country who wanted to murder Jesus because of a prophecy (Matt, 2:16) 'Herod was furious on realising that he had been fooled by the wise men, and in Bethlehem and its surrounding district he had all the male children killed who were two years old or less, reckoning by the date he had been careful to ask the wise men'. In the Chronicles of Narnia, the White Witch wants to kill the four Pevensie siblings for the same reason.

Christ — as in the case of Peter, Susan, Edmund, and Lucy in Narnia - comes to our world to restore the balance, a task implicit in the heroic physiognomy of the protagonists of the Scarecrow Literature. On occasions, it can also occur that children grow while they are in the secondary world and become adults. The important characteristic is that after their heroic mission in the secondary world where the majority of the action takes place, they return to their primary world. Jesus, like the Pevensie, also returns to the primary world from whence He came and leaves the secondary world (the Earth).

It is unusual, but not impossible, that a hero of Scarecrow Literature dies in the secondary world. Such are the cases of Eustace and Jill in The Last Battle (1956). Jill and Eustace die to defend Narnia and the Narnians, while many of these are against them and not believe in God-Creator (Aslan) or his champions. Something similar happens with Jesus. He dies to save mankind to assist them and redeem their sins. Yet many rise up against him and do not want to believe in the new image of a good God and kind Father that Jesus has revealed to them (Luke 23:20-21) 'In his desire to set Jesus free, Pilate addressed them again, but they shouted back, "Crucify him! Crucify him!"

The great gift that our heroes in Scarecrow Literature receive when they return to the primary world from their heroic work in the secondary world is the warmth of the family, and for Christ, the return home is also joyful. 'Jesus described our ultimate destination as a specially prepared part of his own house (...) And He gave the apostle John a glimpse of the unspeakable joy we could expect when God and man finally experience the same reality and share the same home' (Bruner \& Ware, 2005:163-4). To be true, home represents the best place in which the hero can finally rest. (Mark, 16:19) 'And so the Lord Jesus, after he had spoken to them, was taken up into heaven; there at the right hand of God he took his place'.

\section{Conclusion}

To conclude, taking into account the characteristics that define Scarecrow Literature, the heroic schema presented here may help us to see and understand Jesus of Nazareth and other heroes from a different point of view. Another issue would be to clarify what we understand by the warmth of the family or community. However, we leave that for another occasion because we believe it to be a question that is far too specific, highly subjective and tangential at best. 


\section{References}

Barrie, J. M. (1911). Peter and Wendy (2004). USA: Penguin Classics.

Baum, L. F. (1900). The Wonderful Wizard of Oz (2001). New York: Harper Trophy.

Bruner, K., \& Ware, J. (2005). Finding God in the land of Narnia. United States of America: SaltRiver.

Campbell, J. (1949). The Hero With a Thousand Faces. USA: Princeton University Press.

Carrol, L. (1864). Alice's Adventures in Wonderland (1993). USA: Dover Thrift Editions.

Colbert, D. (2005). The Magic Worlds of Narnia: a Treasury of Myths and Legends. England: Penguin.

Dorsett, L. W., \& Lamp, M. (1985). Letters to Children. New York \& London: Collins.

Downing, D. C. (2005). Into the Wardrobe. USA: Jossey-Bass.

Duriez, C. (2002). The C. S. Lewis Encyclopedia. Great Britain: Azure.

Ende, M. (1979). The NeverEnding Story (1997). Stuttgart: Thienemanns Verlag.

Haining, P. (1988). The Scarecrow Fact and Fable. London: Robert Hale.

Hamilton, E. (1942). Mythology. Canada: Mentor Rock.

King, S., \& Straub, P. (1984). The Talisman (2012). New York: Pocket Books.

Kirk, E. J. (2005). The Chronicles of Narnia. Beyond the Wardrobe. The Official Guide to Narnia. Italy: Harper Collins.

Klages, A. (2006). Nativity Thoughts. Retrieved December, 2006, from http://qaz1.bannerland.org/wordpress

Lewis, C. S. (1949). The Lion, the Witch and the Wardrobe (1998). Hong Kong: Collins.

Lewis, C. S. (1951). Prince Caspian (1998). Hong Kong: Collins.

Lewis, C. S. (1955). The Magicians Nephew (1998). Hong Kong: Collins.

Lewis, C. S. (1956). The Last Battle (1998). Hong Kong: Collins.

Montero Gilete, R. (2007). El niño como héroe en la literatura infantil fantástica. Bilbao: Universidad del País Vasco.

Montero Gilete, R. (2009). De la relación del psicoanálisis con Las crónicas de Narnia de C.S. Lewis. Revista de Literatura. Barcelona: CC\&P.

Montero Gilete, R., \& Simoson, M. (2007). El retorno del Espantapájaros. Revista de Literatura. Barcelona: CC\&P.

Montero Gilete, R., \& Simoson, M. (2008). El Espantapájaros y la literatura infantil fantástica. Revista de Literatura. Barcelona: CC\&P.

Pullman, P. (2000). His Dark Materials (2011). New York: Alfred A. Knopf.

Rank, O. (1909). The myth of the birth of the hero; A psychological interpretation of mythology (F. Robbins, \& S. E. Jelliffe, Trans.). New York: R. Brunner.

Rilstone, A. (2006). Enter Into Thy Closet. A neglected aspect of the life and works of C. S. Lewis. Retrieved December, 2006, http://from www. andrewrilstone.blogspot.com/2006/04

Rowling, J. K. (1997). Harry Potter and the Philosopher's Stone (2000). USA: Scholastic.

Shea, A. L. (1993). C.S. Lewis and the Chronicles of Narnia: A study of heroes. Texas: Texas Woman's University.

Tolkien, J. R. R. (1937). The Hobbit (2007). UK: Harper Collins.

Wansbrough, H. (Ed.) (1990). The New Jerusalem Bilble. London: Darton, Longman \& Todd.

\section{Copyrights}

Copyright for this article is retained by the author(s), with first publication rights granted to the journal.

This is an open-access article distributed under the terms and conditions of the Creative Commons Attribution license (http://creativecommons.org/licenses/by/3.0/). 